\title{
Peptic Ulcer as a Disorder of an Unknown Syndrome
}

\section{Andy Petroianu*}

Professor of Surgery, Department of Surgery of the School of Medicine, Federal

University of Minas Gerais, Brazil

*Corresponding Author: Andy Petroianu, Professor of Surgery, Department of Surgery of the School of Medicine, Federal University of Minas Gerais, Brazil.
Received: December 29, 2021

Published: January 01,2022

(C) All rights are reserved by Andy Petroianu.

Keywords: Peptic Ulcer; Etiology; Pathophysiology; Treatment; History; Characteristics

The symptoms of peptic ulcer have been described in all ancient civilizations since the Egyptian papyrus, Babylonian stones and documents from the Hippocratic Greece, China and India literature. The first association of these manifestations with gastric ulcer was made after the sudden death of princess Henriette-Anne, King Charles I's daughter, at the age of 26, a day after she complained of abdominal pain in 1670. In an attempt to understand this disease, Prout (1823) confirmed the active secretion of hydrochloric acid by the stomach and related it to the abdominal pain. Schwann (1836) described and named the pepsin as a stomach enzyme, which also was related to abdominal discomfort. Curveilhier (1829) described gastric ulcers of the lesser curvature, distinguishing benign from malignant ones and due to his relevant works, benign ulcers of the stomach was called "maladie de Cruveilhier". Based on this knowledge, Schwartz (1910) wrote "Ohne saueren Magensaft kein peptisches Geschwür" (no acid in gastric juice, no peptic ulcer). Since that time, the benign gastric and duodenal ulcers are known as chloridropeptic ulcer or peptic ulcer, and all treatments aim to neutralize or inhibit the production of acid and pepsin.

This simplistic medical position does not take into account many characteristics associated with the presence of benign gastric and duodenal ulcers, which are part of a complex syndrome that include multiple manifestations. In this sense, there are some aspects that should be emphasized and considered for further studies.

- Most people with benign ulcers are blood group 0 and other cases of peptic ulcer are present in their families. Very rarely people with peptic ulcers develop gastric cancer. These as- pects indicate the genetic origin of this disorder, so the tendency to have ulcer seems to be congenital and arises in the presence of triggering factors. Patients with benign and malignant gastric ulcers are phenotypically different in most of their characteristics.

- The vast majority of ulcers occur in anxious men and begin in times of intense stress, with peak incidence between 45 and 50 years. This ulcer is also found more often between 25 and 30 years of age. If it were just a chlorhidropeptic disorder, there would be no difference between the genders or a predominance in specific ages.

- $\quad$ Ulcers are generally unique and circumscribed to the mucosal transition regions, between the antral and pyloric mucosa or between the gastric body and antrum mucosae, almost always in the lesser curvature of the stomach, or, in most patients, between the pyloric and duodenal mucosae. If the cause were acid or pepsin, there should be multiple ulcers randomly found in the stomach and duodenum as occurs in gastrinoma. It should also be noted that this single ulcer heals and may recur, remaining as the only cause of symptoms. Rarely, a second peptic ulcer appears in the duodenum and its manifestations are similar. Otherwise, no more than one ulcer is found in the stomach and it does not occur together with duodenal ulcer.

- In presence of a peptic ulcer, the anterior (left) and posterior (right) vagus nerves are two to four times thicker than the vagus nerves of people without ulcers, and their parietal cells produce much more acid than the general population. Although the vagus nerve mediates many neuroendocrine functions, no cardiac, pulmonary or digestive disorder associated 
with this vagal thickening has been found. The number and amount of mediators transmitted by an enlarged vagus is not greater than that of those who have a vagus with normal dimensions.

- $\quad$ Parietal cells are stimulated to produce hydrochloric acid by three main mediators, acetylcholine, histamine and gastrin, however, if only one of these mediators is inhibited, the parietal cells reduce or stop their production, even in the normal presence of the other two mediators. Histamine receptors inhibitors reduce the action of only this mediator, without influencing the magnitude of acetylcholine or gastrin that reaches the parietal cells walls. On the other hand, vagotomy, which interrupts the stimulation of acetylcholine alone, does not interfere with histamine or gastrin and also reduces the acid production.

- Misoprostol is a synthetic prostaglandin E1 analog that was successfully introduced in the treatment of peptic ulcers in 1973. This drug inhibits the production of hydrochloric acid acting in the microcirculation, without a direct impairment of the hydrochloric acid production. It acts on capillary sphincters and dilates both arterioles and venules, preventing ischemia of the gastric mucosa and promoting the ulcer healing. Thus, it seems to be evident that benign gastric and duodenal ulcers are likely to result from mucosal ischemia and can be treated by restoring an adequate blood flow at the ulcer site.

- $\quad$ Since Warren (1937), the presence of Campylobacter pyloridis has been associated with various inflammations of the gastric mucosa. From the 1980s, this bacterium was considered a determinant in the genesis of peptic ulcers as an infection, and the name of the bacterium changed to Helicobacter pylori in 1989. This finding modified the treatment of ulcers, adding antibiotic therapy, with good results and a reduction in ulcer recurrences. However, this bacterium exists in the stomach of more than half of the world population. This bacterium when colonizing an ulcer impairs its healing and in this condition antibiotics are indicated.

Unique benign ulcers of the stomach and duodenum are part of a much-studied but still unknown syndrome in many of its aspects, such as its association with liver cirrhosis, parathyroid disorders and rheumatic disease. Apparently, this disorder is congenital and activating factors, especially those related to stress and ischemia of the transitional mucosa are responsible for starting the wound.
Once established, the ulcer is aggravated by the corrosion of hydrochloric acid and pepsin, in addition to being infected by H. pylori. Therefore, peptic ulcer is only a relevant manifestation of a syndrome that needs to be even better understood.

\section{Assets from publication with us}

- Prompt Acknowledgement after receiving the article

- Thorough Double blinded peer review

- Rapid Publication

- Issue of Publication Certificate

- High visibility of your Published work

Website: www.actascientific.com/

Submit Article: www.actascientific.com/submission.php

Email us: editor@actascientific.com

Contact us: +919182824667 